\title{
Prevalence of TMD among Children Provided with Fixed Orthodontic Treatment
}

\section{Prevalencija temporomandibularnih disfunkcija kod djece podvrgnute fiksnoj ortodontskoj terapiji}

\author{
Department of Orthodontics, School of Dental Medicine, University of Sarajevo, Sarajevo, Bosnia and Herzegovina \\ Zavod za ortodonciju Stomatološki fakulteta Sveučilišta u Sarajevu, Bosna i Hercegovina \\ 2 Department of Prosthodontics, School of Dental Medicine, University of Sarajevo, Sarajevo, Bosnia and Herzegovina \\ Zavod za protetiku Stomatološkog fakulteta Sveučilišta u Sarajevu, Bosna i Hercegovina \\ 3 Primary Health Care Center Bugojno, Bosnia and Herzegovina \\ Dom primarne zdravstvene zaštite Bugojno, Bosna i Hercegovina
}

\begin{abstract}
According to available scientific references and textbooks, there are contradictory views concerning the etiology of signs and symptoms of TMD. Objectives: The aim of this study was to determine a correlation between the incidence of signs and symptoms of TMD in children aged 12-18 who do not wear a fixed orthodontic appliance and the incidence of signs and symptoms of TMD in children who wear a fixed orthodontic appliance. Material and Methods: The total number of 120 subjects were included in this survey and divided into two groups. There were 60 respondents in the experimental group that consisted of 30 boys and 30 girls with different types of malocclusion, who were treated with a fixed orthodontic straight wire technique. The remaining 60 respondents, which was a group that also consisted of 30 boys and 30 girls, were patients with neutroclusion. Results: The results of the study have shown that the TMJ clicking sound symptom, the most common symptom of TMD, occurs with almost equal prevalence in both groups of respondents; specifically, $56.4 \%$ in orthodontic patients, and $46.6 \%$ in the control group respondents. A statistically significantly higher percentage of female respondents in both groups have experienced headache problems $(p<0.03)$. Conclusion: On the basis of the statistics obtained as a result of this research, we can come to the conclusion that there is no correlation between the fixed orthodontic treatment and the development of signs and symptoms of TMD.
\end{abstract}

Received: December 25, 2020 Accepted: April 6, 2021

Address for correspondence Alma Mušanović University of Sarajevo School of Dental Medicine Department of Orthodontics Bolnička 4a, 11000 Sarajevo, Bosnia and Herzegovina

Phone +38761226797; almamaslan@gmail.com

MeSH terms: Temporomandibular Joint Disorders; Fixed Orthodontic Appliances; Adolescent Author keywords: Temporomandibular Disorders; Malocclusion; Orthodontic Treatment

\section{Introduction}

The term Temporomandibular Joint Disorders (TMDs/ TMJDs) has been first used on the recommendation of the American Academy of Orofacial Pain (AAOP) ever since 1993 and it is a common name denoting a number of functional disorders of the temporomandibular joint or orofacial musculature with different etiologies that are differentiated by a diverse clinical picture (1). Stricto sensu, the term Temporomandibular Joint Disorders also includes various muscle function disorders, intracapsular disorders, and degenerative joint diseases (2).

This study deals with the dysfunctions of temporomandibular joints and their adjacent structures, which are manifested as: pain in the area of temporomandibular joints and masticatory musculature; TMJ sounds as a symptom of structural changes within the temporomandibular joints; and limited mobility of the lower jaw (3).

\section{Uvod}

Naziv temporomandibularna disfunkcija (TMD) upotrebljava se na prijedlog Američke akademije za orofacijalnu bol (AACD) od 1993. godine i zajednički je naziv za niz funkcionalnih poremećaja čeljusnoga zgloba ili orofacijalne muskulature različite etiologije s drukčijom kliničkom slikom (1). U užem smislu pod nazivom temporomandibularna disfunkcija podrazumijevaju se i poremećaji funkcije mišića, intrakapsularni poremećaji i degenerativne bolesti zglobova (2).

U ovom istraživanju riječ je o poremećajima funkcije čeljusnih zglobova i susjednih struktura koji se očituju kao bolovi u području čeljusnih zglobova i žvačne muskulature, zvukovi u zglobu kao simptomi strukturnih promjena unutar čeljusnih zglobova te ograničenja u pokretljivosti donje čeljusti (3).

Tegobe prouzročene temporomandibularnim disfunkcijama kronične su i samim tim teže postavljanju dijagnoze jer je teško ustanoviti kada se pojavljuju. 
The problems caused as a result of TMDs are chronic and are by extension more difficult to diagnose, since it is quite difficult to identify the precise moment when these symptoms occur.

Nowadays, 60 to 70 percent of any population suffers from some sort of temporomandibular disorder and the women-men ratio of this pathological condition is 4:1 (4). Approximately, during his/her lifetime, every sixth adult seeks treatment for temporomandibular disorders. Furthermore, there is a widespread representation of all age groups (5), although the symptoms are most common in the age groups between 17 and 30 or between 20 and 40 years of age.

The incidence of temporomandibular disorders among children increases with age and ranges from 6\% to 68\% (68). It has been established that young people in Germany suffer more often from the phenomenon of disc displacement then those living in Asia, where there is a more widespread prevalence of pain in the masticatory musculature and temporomandibular joints (9).

A review of various scientific references has shown that we can identify the following five factors that are associated with temporomandibular disorders: occlusion, trauma, psychological factors, acute pain, parafunctions and inflammations (10-12).

\section{Objectives}

The objectives of the study are as follows: to determine the incidence of signs and symptoms of TMD in orthodontic patients undergoing fixed orthodontic therapy in the age group 12 to 18 years, to determine a correlation between the incidence of signs and symptoms of TMD in a group of respondents not undergoing fixed orthodontic therapy and the incidence of TMD in a group of respondents undergoing fixed orthodontic therapy and to examine whether there is potentially a statistically significant difference between male and female genders in terms of frequency rate of signs and symptoms of TMD.

\section{Material and methods}

During the period from June to October 2015, a survey was conducted to examine a group of children and adolescents aged 12 to 18 who were patients of the Public Institution of Health Care Centre (local hospital) in the town of Fojnica. This research was conducted with voluntary consent given by all respondents and parents of underage children, including the one given by the Ethics Committee of the Faculty of Dentistry of the University of Sarajevo.

The total number of respondents participating in the survey was 120 , of whom 60 , i.e. 30 boys and 30 girls were found to suffer from different types of malocclusion (classified by Angle) and were treated with a fixed orthodontic straight wire technique. The remaining 60 respondents, also including 30 boys and 30 girls, were patients with neutroclusion. The latter respondents constituted a control group or respondents who did not wear fixed orthodontic appliances.

A standardized RDC/TMD protocol was used for the purpose of this research.
Danas se zna da od 60 do $70 \%$ bilo koje populacije pati od neke vrste čeljusnog poremećaja i da omjer toga patološkog stanja između žena i muškaraca iznosi $4: 1$. $^{(4)}$ Otprilike svaka šesta odrasla osoba tijekom života traži tretman zbog temporomandiblarnih disfunkcija. Istaknimo da su zastupljene sve dobne skupine, iako su simptomi najččšći u dobi između 17 i 30 godina ili između 20 i 40 (5).

Za razliku od odraslih, djeca i adolescenti rijetko dolaze stomatologu zbog simptoma TMD-a. Zanimljivo je da se kod te populacije učestalost znakova i simptoma povećava $s$ dobi (6). U postotku je prevalencija znakova i simptoma TMD-a kod djece i adolescenata od 6 do $68 \%(7,8)$. Podgrupe TMD-a ovise o etničkoj pripadnosti pa se i različito očituju kod mladih pacijenata. Tako je ustanovljeno da njemačka mladež češće pati od pomaka diska u odnosu prema mladim Azijcima kod kojih su češći bolovi unutar žvačne muskulature i čeljusnoga zgloba (9).

Etiologija i patofiziologija TMD-a složena je i multifaktorijalna. Pregledom znanstvene literature ustanovljeno je pet čimbenika povezanih s čeljusnim poremećajima - okluzija, trauma, psihološki čimbenici, duboka bol, parafunkcije i upale $(10-12)$.

\section{Svrha istraživanja}

Željela se ustanoviti incidencija znakova i simptoma TMD-a kod ortodontskih pacijenata podvrgnutih fiksnoj ortodontskoj terapiji u dobi od 12 do 18 godina te korelacija između incidencije znakova i simptoma TMD-a kod ispitanika koji nisu podvrgnuti fiksnoj ortodontskoj terapiji i incidencije znakova i simptoma TMD-a kod ispitanika koji su podvrgnuti fiksnoj ortodontskoj terapiji. Trebala se ispitati i moguća statistički značajna razlika između muškoga i ženskoga spola u vezi s učestalošću znakova i simptoma TMD-a.

\section{Materijal i metode}

Od srpnja 2015. do listopada iste godine provodilo se istraživanje u sklopu kojega su ispitivana djeca i adolescenti u dobi od 12 do 18 godina koji su dolazili u J. U. Dom zdravlja u Fojnici. Za ispitivanje je dobivena suglasnost svih ispitanika i roditelja maloljetne djece te Etičkog povjerenstva Stomatološkog fakulteta Sveučilišta u Sarajevu.

Ukupan broj ispitanika uključenih u istraživanje bio je 120 , od kojih je 60 - 30 dječaka i isto toliko djevojčica - imalo različite tipove malokluzije (klasificirane prema Angleu), a tretirani su bili fiksnom ortodontskom tehnikom ravnoga luka. Preostalih 60 ispitanika - također 30 dječaka i 30 djevojčica - bilo je s neutrookluzijom. Oni su činili kontrolnu skupinu te se nisu koristili fiksnim ortodontskim uređajem.

$\mathrm{Za}$ ovo istraživanje primijenjen je standardizirani protokol RDC/TMD.

Pregled ispitanika obavljen je u stomatološkoj ordinaciji s jednakim pristupom za sve sudionike. Najprije je evidentiran dentalni status svih ispitanika i vrsta malokluzije kod onih koji su se koristili fiksnim ortodontskim aparatom. Na- 
Initially, the dental status was recorded for all respondents, including the malocclusion type identified in those patients who wore the fixed orthodontic appliances. Then, the respondents were subjected to an anamnestic and clinical screening based on a standardized RDC/TMD screening examination protocol (13). The RDC/TMD examination protocol consists of two Axes which clarify the relationship between the respondents' psychological and physical findings.

It is widely used in the diagnostics and classification of respondents with masticatory musculature and temporomandibular joint disorders. Axis I is used to identify the physical dysfunctions of masticatory musculature and of jaw joints at the same time. Axis II refers to psychological findings and psychosocial condition found in the respondents, and it is thus used to determine a wide range of behavioural, psychological and psychosocial factors that are extremely important for TMD diagnosis and treatment.

The anamnestic part of the questionnaire consists of a number of questions about pain in the jaw, facial and temple areas, including a number of questions about potential existence of any harmful parafunctional habits such as teeth-grinding/crepitus, or teeth-clenching/locking, etc.. The questionnaire also contains a number of questions about traumatic injuries to the facial area, including also the questions about any professional care provided with regard to the existing problems detected in the respondents.

The clinical part of the study consisted in determining the functional condition of muscles by asking the respondents to indicate any potential presence of pain during palpation of certain muscle areas. Then, the functional condition of the masticatory system was examined. The lower jaw mobility was measured in the vertical (incisal overlap), horizontal (lateral mandibular movement to the left and right side of the midline deviations) and sagittal plains (protrusive mandibular movement). The masticatory musculature and the jaw joint were examined for the signs of any potential pain during palpation, but in addition to that the temporomandibular joint was also examined for the signs of any potential existence of TMJ clicking/popping/cracking sounds. The average time required per clinical examination was 10 minutes.

\section{Statistical analysis}

Statistical data processing was performed by using the IBM SPSS Statistics V21 software package. Descriptive statistical parameters that were calculated included the arithmetic means and the corresponding standard deviation of variables, and then the absolute frequencies and percentages. Testing of the research hypotheses was performed by using various parametric and non-parametric statistical methods, depending on the statistical assumptions made for the particular methods. Student t-test of independent samples was used as the parametric method, while Mann-Whitney U-test, Pearson's chi-square test, and chi-square test with Yates correction were used as the non-parametric methods. Research hypotheses were tested on an alpha level of $95 \%$, i.e. $5 \%$ risk (0.05). kon toga su ispitanici podvrgnuti anamnestičkom i kliničkom ispitivanju na temelju standardiziranoga protokola za ispitivanje RDC/TMD-a (13). Sastoji se od dviju osovina koje objašnjavaju vezu između psihičkoga i fizičkoga nalaza ispitanika. Koristi se u dijagnostici i klasifikaciji ispitanika s poremećajem žvačnih mišića i čeljusnoga zgloba. Osovinom I istodobno se određuje fizička disfunkcija žvačnih mišića i čeljusnih zglobova. Osovina II odnosi se na psihološke nalaze i psihosocijalno stanje ispitanika pa se primjenjuje za određivanje ponašanja, psiholoških i psihosocijalnih čimbenika iznimno važnih za dijagnosticiranje i liječenje čeljusnih poremećaja.

Anamnestički dio upitnika sastoji se od pitanja o bolovima u području čeljusti, lica i sljepoočnice te pitanja o mogućim štetnim navikama (škripanje zubima, stiskanje zuba). Upitnik sadržava i pitanja o traumama u području lica i o profesionalnoj zbrinutosti postojećih tegoba kod ispitanika.

Klinički dio ispitivanja odnosio se na utvrđivanje funkcionalnog stanja mišića tako što su se ispitanici izjašnjavali osjećaju li bol pri palpaciji određenih mišićnih područja. Nakon toga je slijedilo ispitivanje funkcionalnog stanja žvačnog sustava. Mjeren je kapacitet pokretljivosti donje čeljusti u vertikalnoj (preklop sjekutića), horizontalnoj (lateralne kretnje mandibule na lijevu i desnu stranu, devijacija sredine) i sagitalnoj ravni (protruzijska kretnja mandibule). Žvačni mišići i čeljusni zglob ispitivani su i zbog mogućih bolova pri palpaciji, a čeljusni zglob dodatno i na postojanje zvukova. Kliničko ispitivanje trajalo je u prosjeku 10 minuta.

\section{Statistička analiza}

Obrada podataka obavljena statističkim softverom IBM SPSS Statistics V21. Od deskriptivnih statističkih parametara izračunate su aritmetičke sredine te pripadajuće standardne devijacije varijabli, zatim apsolutne frekvencije i postotci. Testiranje istraživačkih hipoteza obavljeno je parametrijskim i neparametrijskim statističkim metodama, ovisno o statističkim pretpostavkama pojedinih metoda. Od parametrijskih metoda korišten je Studentski t-test nezavisnih uzoraka, a od neparametrijskih Mann-Whitneyev U-test, Pearsonov hikvadrat test te hi-kvadrat test s Yatessovom korekcijom. Istraživačke hipoteze testirane su na razini alfa od $95 \%$, tj. $5 \%$ rizika $(0,05)$. 


\section{Results}

Pain in the facial, jaw and/or temple areas, in front of the ear or in the ear was felt during the previous month almost equally by both groups - i.e. the respondents wearing a fixed orthodontic appliance and those who were not wearing such an appliance. Consequently, there is no statistically significant difference between the analysed groups of respondents with the probability of $p<1$. A slightly higher percentage of female respondents wearing a fixed orthodontic appliance have experienced pain in the abovementioned areas during the previous month compared with male respondents. The chi-square test did not show any statistical significance with a probability of $\mathrm{p}<0.350$ as presented in Table 1 .

As for the respondents who did not wear a fixed orthodontic appliance, $13.3 \%$ of female respondents felt pain in the facial, jaw and/or temple areas, in front of the ear or in the ear during the previous month compared with male respondents who did not experience such a phenomenon.

On average, a slightly stronger intensity of pain in the facial area was felt by the respondents who wore a fixed appliance compared with those who did not wear the appliance. Nevertheless, the Mann Whitney U-test did not show any statistically significant results.

During the examination of TMD symptoms, the majority of respondents in both groups had a TMJ clicking sound symptom during opening and closing movements of the mouth; specifically, $53.4 \%$ of the respondents with a fixed orthodontic appliance and $46.6 \%$ of the control group respondents.

Headache pain was confirmed by $15 \%$ of respondents who wore a fixed orthodontic appliance and by $16.7 \%$ of those who did not wear the appliance, which suggests that there is no statistically significant correlation between the existence of headache problem and the wearing of a fixed orthodontic appliance, which was proved by the chi-square test shown in Table 2.

\section{Rezultati}

Bol u području lica, čeljusti, sljepoočnice te ispred uha ili u uhu u posljednjih mjesec dana približno su podjednako osjećali i ispitanici koji upotrebljavaju fiksni aparat i oni koji se njime ne koriste. Prema tome, ne postoji statistički signifikantna razlika između analiziranih skupina uz vjerojatnost od $\mathrm{p}<1$. Neznatno veći postotak ispitanica koje se koriste fiksnim aparatom osjetilo je bol u navedenim područjima u posljednjih mjesec dana, u usporedbi s ispitanicima. Hi-kvadrat test nije dokazao statističku signifikantnost uz vjerojatnost od $\mathrm{p}<0,350$, što je predstavljeno u tablici 1 .

Kada je riječ o ispitanicima koji se nisu koristili fiksnim aparatom, 13,3\% ispitanica osjećalo je bol u području lica, čeljusti, sljepoočnice, ispred uha ili u uhu u posljednjih mjesec dana u usporedbi s ispitanicima kod kojih nije bilo takve pojave.

U prosjeku su nešto jaču bol u području lica osjetili ispitanici koji su se koristili fiksnim aparatom u usporedbi s onima koji nisu. MannWhitneyjev U-test nije pokazao statistički značajne rezultate.

Pri ispitivanju simptoma TMD-a najviše ispitanika iz obiju grupa imalo je simptom škljocanja pri otvaranju/zatvaranju usta i to $53,4 \%$ ispitanika koji se koriste fiksnim ortodontskim aparatom i 46,6 \% onih iz kontrolne skupine.

Glavobolju je potvrdilo $15 \%$ ispitanika s fiksnim ortodontskim aparatom i 16,7 \% onih koji takav aparat ne nose, tako da ne postoji statistički značajna povezanost problema s glavoboljom i korišstenjem fiksnoga ortodontskog aparata, što je dokazano Hi-kvadrat testom prikazanim u tablici 2.

Statistički značajno veći postotak ispitanica, i u skupini $s$ fiksnim aparatom $(\mathrm{p}<0,030)$ i u kontrolnoj skupini $(\mathrm{p}<$ $0,0,15)$, imao je problema s glavoboljom ili migrenom u posljednjih šest mjeseci u usporedbi s ispitanicima.

Kad je riječ o osjećaju boli u području lica na desnoj, lijevoj ili objema stranama, nešto veći postotak, ali ne statistički

\begin{tabular}{|c|c|c|c|c|c|c|c|}
\hline \multirow{3}{*}{\multicolumn{2}{|c|}{$\begin{array}{l}\text { Have you felt pain in the facial, jaw or temple areas, in front of the ear or in the ear } \\
\text { during the last month? • Jeste li osjetili bol u području lica, čeljusti, sljepoočnice, ispred } \\
\text { uha ili u uhu u posljednjih mjesec dana? }\end{array}$}} & \multicolumn{4}{|c|}{ Gender $\bullet$ Spol } & & \\
\hline & & \multicolumn{2}{|c|}{ Male • Muško } & \multicolumn{2}{|c|}{ Female • Žensko } & \multicolumn{2}{|c|}{ Total • Ukupno } \\
\hline & & $\mathrm{n}$ & $\%$ & $\mathbf{N}$ & $\%$ & $\mathrm{~N}$ & $\%$ \\
\hline & $\mathrm{No} \bullet \mathrm{Ne}$ & 29 & 96.7 & 26 & 86.7 & 55 & 91.7 \\
\hline & Yes $\bullet \mathrm{Da}$ & 1 & 3.3 & 4 & 13.3 & 5 & 8.3 \\
\hline \multicolumn{2}{|c|}{ Total • Ukupno } & 30 & 100 & 30 & 100 & 60 & 100 \\
\hline
\end{tabular}

Table 2 Presence of headache or migraine problems over the past 6 months Tablica 2. Prisutnost glavobolje ili migrene u posljednjih 6 mjeseci

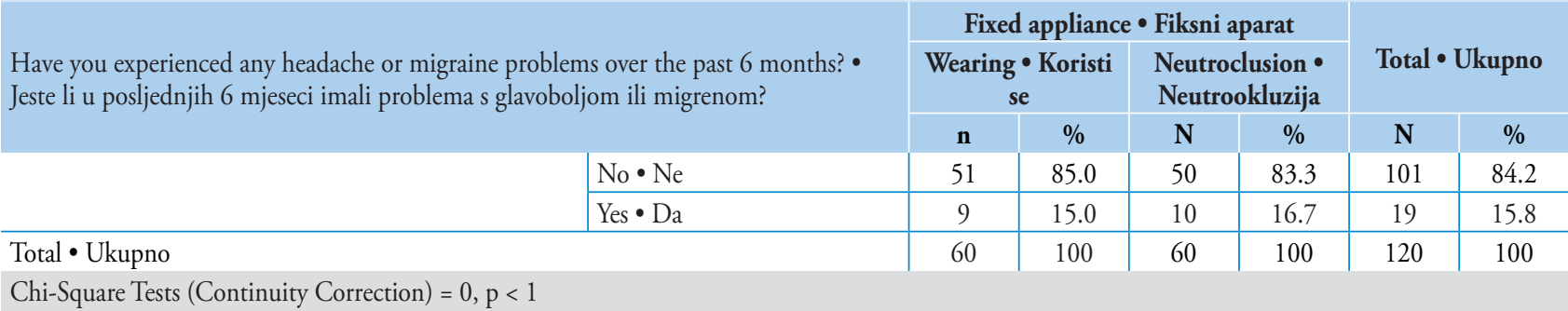




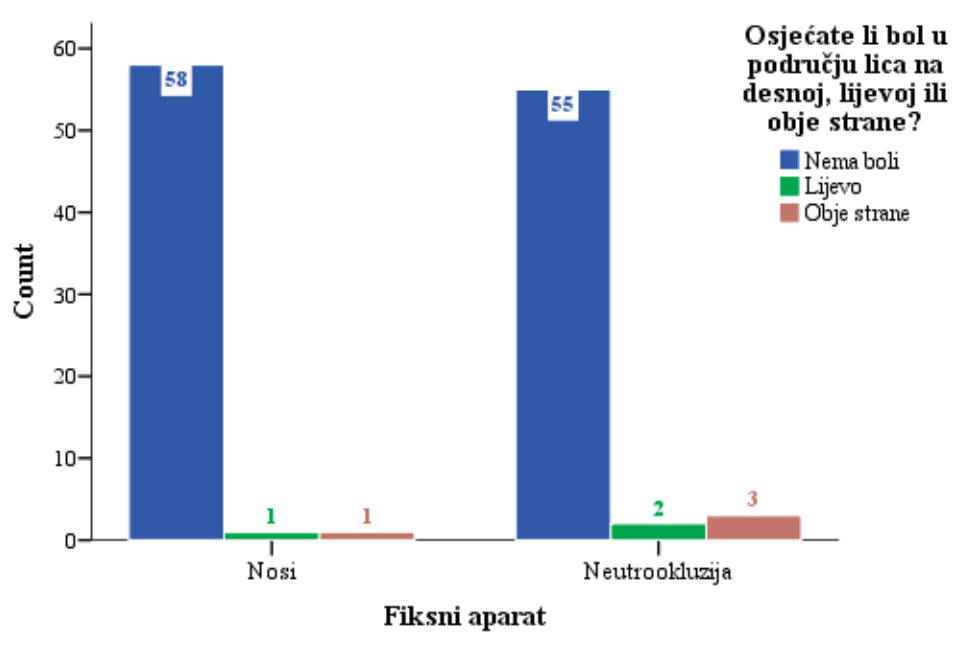

Figure 1 An analysis of pain felt in the facial area on the right, left or either side among the respondents with and without a fixed orthodontic appliance

Slika 1. Analiza osjećaja boli u području lica na desnoj, lijevoj ili objema stranama lica između ispitanika koji se koriste ili ne koriste fiksnim aparatom

A statistically significantly higher percentage of female respondents in both groups, the group wearing a fixed orthodontic appliance, $(\mathrm{p}<0.030)$, and the control group, $(\mathrm{p}$ $<0.0 .15$ ), have reported headache or migraine problems over the past six months compared with male respondents.

So far as the feeling of pain in the facial area on the right, left or either side is concerned, a slightly higher, but not statistically significant percentage of those who were in neutroclusion have confirmed the presence of pain on the left or either side (8.3\%). Only $3.4 \%$ of the respondents wearing a fixed orthodontic appliance have experienced pain on the left or either side of the face as shown in Figure 1.

The largest proportion of respondents has demonstrated a straight jaw opening pattern. A corrected right deviation was reported in $7(11.7 \%)$ respondents with a fixed appliance and in $4(6.7 \%)$ respondents from the control group, while a corrected left deviation was reported in $9(15 \%)$ respondents with a fixed appliance and in $7(11.7 \%)$ respondents from the control group.

When assessing the pain on the right and left side in the maximum unassisted opening and maximum assisted opening in relation to respondents' gender, those who wore a fixed appliance were reported to have had joint and muscle pain $(10 \%)$, which was particularly pronounced in female respondents, while those who did not wear a fixed appliance were reported to have shown signs of the presence of muscle pain only $(10 \%)$.

The prevalence of mouth opening and closing clicks ranged between $5 \%$ in the respondents with neutroclusion during opening of the mouth to the right side and $20 \%$ in the same group of respondents during opening of the mouth to the left side. The respondents wearing a fixed orthodontic appliance were reported to have had a lower prevalence of clicks while opening or closing the mouth.

A small number of respondents in this study showed muscular sensitivity during palpation. Approximately onethird of the respondents, $(35 \%)$, who wore a fixed orthodontic appliance, experienced some pain during the muscle palpation, particularly during palpation of intraoral muscles, specifically the Temporalis muscle tendon (16.6\%). The prev- značajan, pojavio se kod onih koji su u neutrookluziji potvrdili kao bol na lijevoj ili objema stranama lica $(8,3 \%)$. Samo 3,4 \% ispitanika koji se koriste fiksnim aparatima osjetilo je bol na lijevoj ili objema stranama lica, što je prikazano na grafikonu broj 1 .

Kad je riječ o kretanju mandibule, najviše ispitanika u ovom istraživanju imalo je ravan oblik otvaranja čeljusti. Desnu ispravljenu devijaciju imalo je $7(11,7 \%)$ ispitanika s fiksnim aparatom i $4(6,7 \%)$ iz kontrolne skupine, a lijevu ispravljenu devijaciju imalo $9(15 \%)$ ispitanika koji se koriste fiksnim aparatom i 7 (11,7\%) iz kontrolne skupine.

Pri procjeni boli na desnoj i lijevoj strani kod maksimalnog neasistiranog i maksimalno asistiranog otvaranja u odnosu prema spolu ispitanika, kod onih koji su se koristili fiksnim aparatom zapažena je pojava boli u zglobu i mišicíima $(10 \%)$, posebno kod ispitanica, a kod ispitanika koji ne upotrebljavaju fiksni aparat bol se pojavljivala samo u mišicíima (10\%).

Prevalencija škljocanja pri otvaranju i zatvaranju usta kretala se između $5 \%$ kod ispitanika u neutrookluziji tijekom otvaranja usta na desnoj strani i $20 \%$ u istoj skupini, ali pri otvaranju na lijevoj strani. Ispitanici koji se koriste fiksnim ortodontskim aparatom imali su manju prevalenciju škljocanja pri otvaranju ili zatvaranju usta.

U ovom istraživanju malo je ispitanika pokazalo osjetljivost mišića pri palpaciji. Otprilike jedna trećina njih (35\%) koji se koriste fiksnim ortodontskim aparatom osjetila je bol pri palpaciji mišića, posebno tijekom palpacije intraoralnih mišića i to tetive $m$. temporalis (16,6 \%). Prevalencija mišićne boli kod ispitanika u kontrolnoj skupini iznosila je $10 \%$, pri čemu je i u toj skupini bol najčešće uočena pri palpaciji tetive $m$. temporalis $(6,6 \%)$. 
alence of muscle pain in the control group respondents was $10 \%$, where the most common pain reported to be observed in this group occurred during palpation of the Temporalis muscle tendon (6.6\%).

\section{Discussion}

Some relevant statistics show that the first TMD symptoms begin to occur specifically in the puberty period, in children and adolescents, and they are more pronounced in girls than in boys. This also coincides with the start of orthodontic therapy, which is received mainly at a young age. Accordingly, the abovementioned statistical data might lead to a number of incorrect conclusions about the TMD etiology. The TMD etiology and pathophysiology are still not clearly explained, which is why a great number of references have been made to a multifactorial etiology that is influenced by numerous and various causative factors involved in the TMD development. A fixed orthodontic therapy is considered to be one of the potential factors responsible for the occurrence of these dysfunctions. Since the orthodontic therapy is administered for a minimum period of two years, there is a possibility that the TMD signs may occur during or after an orthodontic treatment, which is why the patients tend to attribute responsibility for the development of signs and symptoms of TMD directly to orthodontists. However, as a matter of fact, the responsibility for this phenomenon cannot be attributed to orthodontic therapy alone, but also to a growing perception of subjective symptoms and the presence of mood disorders or increased sensitivity in patients, particularly among girls. This is also supported by the fact that during puberty, due to an accelerated rate of growth and development, there is an increase in the number of TMD objective findings. In order to ensure an adequate level of protection for orthodontists, the recommendation would be to examine the functional condition of the masticatory system prior to the very start of orthodontic therapy and to have it controlled preferably every 6 months during the treatment.

Bearing in mind the fact that various scientific references and textbooks discuss the impact of age on the prevalence of signs and symptoms of TMD, the authors of this study have also come to conclusion that the prevalence of signs and symptoms of TMD increases with age (14-17).

A detailed analysis of an epidemiological study conducted by Magnusson et al.(18,19), shows that persons in the age group between 15 and 25 years show a higher prevalence of signs and symptoms of TMD compared with those in the age group between 25 and 30 years, while the latter age group shows a significant decrease in the prevalence. This can be explained by referring to a longer duration of muscle tenseness that occurs in the older age and causes intracapsular changes. With that in mind, we can also explain the assumption that muscle dysfunctions may sometimes precede the problems occurring within the joint itself (20). It can be concluded that younger persons show a remarkable degree of adaptability of their muscular system and orofacial muscles to such changes, which eventually reduces the visibility of TMD symptoms (21).

\section{Rasprava}

TMD se smatra glavnim uzrokom neodontogene boli u području orofacijalne regije. Posljednjih se godina velika pozornost posvećuje disfunkcijama čeljusnoga zgloba s obzirom na to da se pacijenti žale na nelagodnosti koje se odnose na kompleks simptoma TMD-a. Podatci pokazuju da se prvi simptomi temporomandibularnih disfunkcija počinju pojavljivati upravo u pubertetu, a kod djece i mladeži izraženiji su kod djevojčica nego kod dječaka. Ujedno se to poklapa s početkom ortodontske terapije koja se uglavnom provodi u mlađoj dobi. Na osnovi ovoga mogu slijediti pogrešni zaključci o etiologiji TMD-a. Etiologija i patofiziologija čeljusnoga poremećaja još uvijek nije do kraja objašnjena pa se govori o multifaktorijalnoj etiologiji na koju utječu mnogobrojni i različiti uzročni čimbenici uključeni u nastanak TMD-a. Fiksna ortodontska terapija razmatra se kao jedan od mogućih čimbenika odgovornih za nastanak tih disfunkcija. $S$ obzirom na to da ortodontska terapija traje najmanje dvije godine, postoji mogućnost da se znakovi temporomandibularnih disfunkcija pojave tijekom ortodontskog tretmana ili poslije njega, pa zbog toga pacijenti ortodontima pripisuju odgovornost za nastanak znakova i simptoma TMD-a. No činjenica je da nije samo ortodontska terapija odgovorna za to, nego je povećana percepcija subjektivnih simptoma, a ujedno je prisutan poremećaj raspoloženja, odnosno povećana osjetljivost, posebno kod djevojaka. Tomu ide u prilog i činjenica da je u pubertetu, zbog ubrzanog rasta i razvoja, više objektivnih nalaza TMD-a. Da bi ortodonti bili zaštićeni, predlaže se ispitivanje funkcionalnog stanja žvačnog sustava prije početka ortodontske terapije i, ako je moguće, tijekom tretmana kontrola svakih 6 mjeseci.

S obzirom na to da se u literaturi govori o utjecaju godina na prevalenciju znakova i simptoma TMD-a, i u ovom istraživanju autori su zaključili da s dobi raste prevalencija znakova i simptoma toga poremećaja $(14-17)$.

$\mathrm{Na}$ temelju epidemiološke studije koju su proveli Magnusson i suradnici, osobe između 15 i 25 godina imaju veću prevalenciju znakova i simptoma TMD-a u odnosu prema onima između 25 i 30 godina kada prevalencija značajno opada $(18,19)$. To se može objasniti duljom mišićnom tenzijom u poodmaklim godinama koja uzrokuje intrakapsularne promjene. $S$ tim u vezi može se objasniti pretpostavka da mišićna disfunkcija može prethoditi problemima unutar zgloba (20). Na kraju se može istaknuti da mlađe osobe pokazuju iznimnu sposobnost adaptacije mišićnoga sustava i orofacijalnih mišića, što smanjuje simptome TMD-a (21).

Uzimajući u obzir pitanja koja se odnose na prisutnost simptoma TMD-a, većina ispitanika istaknula je da čuje zvukove škljocanja. U ovom istraživanju zabilježen je češći nalaz škljocanja s porastom dobi. U skupini ispitanika koji se koriste fiksnim aparatom njih 53,4\% potvrdilo je prisutnost 
In their response to the questions relating to the presence of TMD symptoms, most respondents have reported the presence of TMJ clicking sounds (clicks). This study confirms a more frequent finding of clicks with increasing age. In the group of respondents who wore a fixed orthodontic appliance, $53.4 \%$ of them have confirmed the presence of this symptom. In the group of respondents who did not wear the appliance, $46.6 \%$ of the respondents have reported the presence of clicks. This also coincides with the findings of other studies, such as the one conducted by Henrikson et al. in 2000, where an increasing rate of prevalence of clinically identified TMJ clicking sounds within the temporomandibular joint was found in all three respondent groups. (22) Different results were obtained in this study relating to the clinically identified TMJ clicking sounds compared with equal sounds indicated in the anamnestic file. There is a greater prevalence of signs compared with the prevalence of symptoms, which can be explained by the assumption that persons wearing a fixed orthodontic appliance tend to avoid excessive mandibular movements that could cause a TMJ clicking sound. Some longitudinal studies (23.24) also show a greater prevalence of TMD signs compared with the prevalence of TMD symptoms.

Magnusson et al. reveal a high prevalence of signs and symptoms of TMD, particularly the sounds, with the highest prevalence found in the respondents between 15 and 25 years of age (25). In such cases, in order to avoid any potential complicating factors, the best recommendation would be to discontinue the orthodontic treatment temporarily until the signs and symptoms of TMD (especially pain) subside. According to Michelotti et al., in the event that the TMDs are diagnosed during the patient's first visit, orthodontic treatment should not be initiated as long as a patient suffers from facial pain (26).

A statistically significantly higher percentage of female respondents in the group of respondents wearing a fixed orthodontic appliance have experienced headache or migraine problems in the last six months compared with the male respondents from the same group, where the percentage was lower $(p<0.030)$. Also, a higher percentage of female respondents from the group without a fixed appliance $(p<0.015)$ was reported to have had headache problems in the last six months compared with the male respondents from the same group. A survey conducted by Julie Hoffmann and Hirsch in 2015, involving 1100 children, some of whom were subjected to orthodontic therapy, came to the conclusion that the prevalence of pain in women was statistically significantly higher compared with such prevalence in men (27).

The arithmetic mean value of maximum unassisted mouth opening in the respondents who did not wear a fixed orthodontic appliance was $51.88 \mathrm{~mm}$, while the value in those with a fixed orthodontic appliance was $52.08 \mathrm{~mm}$. The female respondents in both groups had somewhat lower values compared with the male respondents. A survey conducted by Ortega et al. examined the existence of a relationship between an orthodontic treatment administered for Class II malocclusions and the development of signs and symptoms of TMD. The findings of this survey suggest that orthodon- toga simptoma. U skupini ispitanika koji se ne koriste aparatom, njih 46,6 \% imalo je zvukove škljocanja, tako da je približno isti broj odgovorio potvrdno na to pitanje. To se slaže s drugim istraživanjima, kao što je na primjer ono Henriksona i suradnika iz 2000. u kojemu je pronađena povećana prevalencija klinički ustanovljenih škljocanja unutar čeljusnoga zgloba u svim trima skupinama ispitanika (22). U ovom istraživanju ustanovljeni su različiti rezultati koji se odnose na kliničko utvrđeno škljocanje i na one koji su navedeni u anamnezi. Veća je prevalencija znakova u odnosu prema simptomima, što se može objasniti pretpostavkom da osobe koje se koriste fiksnim ortodontskim aparatom izbjegavaju pretjerane kretnje čeljusti koje bi izazvale škljocanje. Longitudinalne studije također pokazuju veću prevalenciju znakova nego simptoma TMD-a $(23,24)$.

Magnusson i suradnici otkrivaju visoku prevalencoju znakova i simptoma TMD-a, posebno zvukova, s najvećom prevalencijom kod onih između 15 i 25 godina (25). Zbog toga je kontinuirano praćenje TMD-a iznimno važno za otkrivanje početnih znakova i simptoma toga poremećaja. U tim slučajevima preporučuje se privremeno prekinuti ortodontski tretman kako bi se izbjegli mogući otegotni čimbenici dok se znakovi i simptomi, posebno bolovi, ne smanje. Ako se TMD dijagnosticira tijekom prvog posjeta pacijenta, ortodontski tretman ne bi trebao niti početi, prema Michelotti i suradnicima, sve dok pacijent pati od bolova u području lica (26).

Statistički značajno veći postotak ispitanica, u skupini koja se koristi fiksnim aparatom, imao je problema s glavoboljom ili migrenom u posljednjih šest mjeseci u usporedbi $s$ ispitanicima iz iste skupine, u kojoj je njihov postotak manji $(\mathrm{p}<0,030)$. Također je veći postotak ispitanica iz skupine bez fiksnog aparata $(\mathrm{p}<0,015)$ imao problema s glavoboljom u posljednjih šest mjeseci u usporedbi $s$ ispitanicima iz iste skupine. U studiji Julie Hoffmann i Hirscha iz 2015. godine u kojoj je sudjelovalo 1100 djece, od kojih je jedan dio bio na ortodontskoj terapiji, autori ističu da je prevalencija boli kod žena statistički značajno veća u odnosu prema muškarcima (27).

Vrijednost aritmetičke sredine maksimalnog neasistiranog otvaranja usta kod ispitanika koji se ne koriste fiksnim aparatom iznosi $51,88 \mathrm{~mm}$, a kod onih koji ga ne rabe iznosi $52,08 \mathrm{~mm}$. Ispitanice su u objema skupinama imale nešto niže vrijednosti u odnosu prema ispitanicima. $U$ istraživanju Ortege i suradnika ispitivana je povezanost ortodontskog tretmana II. klase malokluzije i razvoja TMD-a. Istaknuli su da ortodontski tretman ne utječe na opseg otvaranja usta. Najveći broj pacijenata otvarao je usta u normalnom opsegu, a samo jedan ispitanik naveo je ograničeno otvaranje usta, no samo privremeno $(28,29)$.

Ispitanici koji se koriste fiksnim ortodontskim aparatom imali su manju prevalenciju škljocanja pri otvaranju ili zatvaranju usta, što pokazuje da nema povezanosti između korištenja fiksnog ortodontskog aparata i pojave škljocanja pri otvaranju i zatvaranju usta. Zapaženo je da je kod nešto većeg broja ispitanica u objema skupinama bila prisutna ta pojava. Drugi autori navode da se prevalencija zvukova unutar zgloba, kao jedan od najčešćih kliničkih znakova temporomandibularnih disfunkcija, kreće od 12 do $48 \%$ (30, 31). 
tic treatment does not affect the maximum range of active mouth opening. The majority of patients have opened their mouth within the normal range and only one respondent had a limited opening of the mouth that was temporary. Mouth opening depends on the individual physical proportions of an individual $(28,29)$.

The respondents who wore a fixed orthodontic appliance were reported to have had a lower prevalence of TMJ clicking sound that occurred during opening or closing movements of the mouth, which suggests that there is no correlation between the wearing of a fixed orthodontic appliance and the occurrence of TMJ clicking sounds during opening and closing movements of the mouth. It was observed that this phenomenon was present in a slightly larger number of female respondents in both groups. Other authors found that the prevalence of TMJ sounds, as one of the most common clinical signs of temporomandibular dysfunctions, ranges from $12 \%$ to $48 \%(30,31)$.

A small number of respondents in this study showed the signs of muscular sensitivity during palpation. In both groups of respondents, women were reported to have a higher prevalence of muscle pain compared with men. This finding was also in line with the results of research conducted by a number of other authors $(32,33)$.

\section{Conclusion}

On the basis of the statistics obtained as a result of this research, we can come to the conclusion that the straight wire technique, as a form of fixed orthodontic therapy, has not shown any correlation with the presence of signs and symptoms of TMD.

\section{Conflict of interest}

None declared

Author's contribution: The authors confirm contribution to the paper as follows: M.A., A.M. - Study conception and design; A.M. - Data collection; L.K., S.T.P., J.M.D. - Analysis and interpretation of results; A.M., S.S.P. - Draft manuscript preparation; L.R.V. - Critical revision of the article. All authors reviewed the results and contributed to the final version of the manuscript.
Najveći dio ispitanika, kako u skupini s fiksnim aparatom tako i u onoj bez toga pomagala, pri lateralnim kretnjama donje čeljusti te tijekom protruzijske kretnje nije imao zglobne zvukove, dok je kod vrlo malog postotka ispitanika zabilježeno škljocanje.

$\mathrm{U}$ ovom istraživanju malo je ispitanika pokazalo osjetljivost mišića pri palpaciji. U objema skupinama kod žena je zabilježena veća prevalencija mišićne boli u odnosu prema muškarcima. To se slaže i sa zaključcima autora drugih istraživanja $(32,33)$.

\section{Zaključak}

$\mathrm{Na}$ osnovi dobivenih statističkih rezultata u ovoj istraživačkoj studiji možemo zaključiti da tehnika ravnoga luka i fiksna ortodontska terapija nisu povezane s prisutnošću znakova i simptoma temporomandibularnih disfunkcija.

\section{Sukob interesa}

Autori nisu bili u sukobu interesa.

Doprinos autora: Autori potvrđuju doprinos radu na sljedeći način: $\mathbf{M}$. A., A. M. - koncipiranje i dizajn studije; A. M. - prikupljanje podataka; L. K., S. T. P., J. M. D. - analiza i interpretacija rezultata; A. M., S. S. P. - nacrt pripreme rukopisa; L. R. V. - kritička revizija članka. Svi autori pregledali su rezultate i dali svoj doprinos konačnoj verziji rukopisa.
Sažetak

U dostupnoj literaturi postoje oprečna mišljenja kad je riječ o etiologiji znakova i simptoma temporomandibularnih, tj. čeljusnih disfunkcija. Svrha rada: Cilj istraživanja bio je ustanoviti korelaciju između incidencije znakova i simptoma TMD-a kod djece od 12 do18 godina koja se ne koriste fiksnim ortodontskim aparatom i incidenciju znakova i simptoma TMD-a kod djece koja se njime koriste. Materijal i metode: U ovom istraživanju sudjelovalo je ukupno 120 ispitanika, a bili su podijeljeni u dvije skupine. Njih 60 iz eksperimentalne skupine - 30 dječaka i 30 djevojčica s različitim tipovima malokluzija - bilo je u tretmanu fiksnom ortodontskom tehnikom ravnoga luka. Preostalih 60 - takoder 30 dječaka i isto toliko djevojčica - bilo je s neutrookluzijom. Rezultati: Rezultati istraživanja pokazuju da se simptom škljocanja, kao jedan od najčešćih znakova TMD-a, pojavljuje približno jednako u objema skupinama ispitanika u postotku od $56,4 \%$ kod ortodontskih pacijenata i $46,6 \%$ kod ispitanika u kontrolnoj skupini. Statistički je značajno veći postotak ispitanica u objema skupinama imalo problem s glavoboljom $(\mathrm{p}<0,03)$. Zaključak: Na temelju dobivenih statističkih rezultata možemo zaključiti da ne postoji povezanost između fiksnoga ortodontskog tretmana i pojave znakova i simptoma temporomandibularnih disfunkcija.
Zaprimljen: 25. prosinca 2020. Prihvaćen: 6. travnja 2021.

Adresa za dopisivanje Alma Mušanović Sveučilište u Sarajevu Stomatološki fakultet Zavod za ortodonciju Bolnička 4 a,

11000 Sarajevo, Bosna i Hercegovina telefon: +38761226797; almamaslan@gmail.com

MeSH pojmovi: poremećaji čeljusnog zgloba; fiksne ortodontske naprave; adolescenti

Ključne riječi: temporomandibularni poremećaji, malokluzija, ortodontski tretman 


\section{References}

1. Valentić- Peruzović M, Jerolimov V, editors. Temporomandibularni poremećaji- multidisciplinarni pristup. Stomatološki fakultet Sveučilišta u Zagrebu i Akademija medicinskih znanosti Hrvatske, Zagreb; 2007.

2. Stark T. Temporomandibuläre Dysfunktionen bei Zahnmedizinstudenten unter besonderer Berücksichtigung der Okklusion, Aus dem medizinischen Zentrum für Zahn-, Mund-, und Kieferheilkunde Poliklinik für Kieferorthopädie des Universitätsklinikums Gießen; 2005.

3. Kropmans TJ, Dijkstra PU, Stegenga B, Stewart R, de Bont LG. The scope of TMD/orofacial pain (head and neck pain management) in contemporary dental practice. Dental Practice Act Committee of the American Academy of Orofacial Pain. J Orofac Pain. Winter 1997;11(1):78-83.

4. Dimitroulis G. Temporomandibular disorders: a clinical update. Brit Med J. 1998 Jul 18;317(7152):190-4.

5. Al-Jundi MA, John MT, Setz JM, Szentpetery A, Kuss O. Meta-analysis of treatment need for temporomandibular disorders in adult nonpatients. J Orofac Pain. Spring 2008;22(2):97-107.

6. Mintz SS. Craniomandibular dysfunction in children and adolescents: a review. J Craniomandib Pract11:224-231, 1993.

7. Hirsch C. Kraniomandibuläre Dysfunktionen (CMD) bei Kindern und Jugendlichen. Oralprophylaxe \& Kinderzahnheilkunde. 2007; 29: $42-6$.

8. de Sena MF, Késsia Suênia F, de Mesquita FR, Santos R. Prevalence of TM dysfunction in children and adolescents. Rev Paul Pediatr. 2013;31(4):538-545.

9. Wu N, Hirsch C. Temporomandibular disorders in German and Chinese adolescents. J Orofac Ortho. 2010 May;71(3):187-98.

10. Okeson JP. Oerofacial pain. Guidelihnes for Assessment, Diagnosisand Menagement. 3 rd ed. Chicago: Quintessence; 1996. p. 119.

11. Ajanović M. Odnos okluzalnih interferenci, simptoma i znakova temporomandibularnih disfunkcija [dissertation]. Sarajevo: Stomatološki fakultet Univerziteta u Sarajevu; 2009.

12. Manfredini D. Current concepts on temporomandibular disorders. London: Quintessence; 1999.

13. Dworkin SF, LeResche L. Research diagnostic Criteria for temporomandibular disorders: review, criteria, examinations and specifications, critique. J Craniomandib Disord. Fall 1992;6(4):301-55.

14. Čelar AG, Bantleon HP. Kraniomandibuläre Dysfunktion: Review und Analyse. Inf Orthod Kieferorthop. 2004;36:1-8.

15. Kuttila M, Niemi PM, Kuttila S, Alanen P, Le Bell Y. TMD treatmentneed in relation to age, gender, stress, and diagnostic subgroup. J Orofac Pain. 1998;12(1):67-74.

16. Rantala MA, Ahlberg J, Suvinen TI, Nissinen M, Lindholm H, Savolainen A, Kononen M. Temporomandibular joint related painless symptoms, orofacial pain, neck pain, and psychosocial factors among nonpatients. Acta Odontol Scand. 2003;61(4):217222.

17. Yap AU, Dworkin SF, Chua EK, List T, Tan HH. Prevalence oftemporomandibular disorder subtypes, psychologic distress, andpsychosocial dysfunction in Asian patients. J Orofac Pain. 2003;17(1):21

18. Magnusson T, Egermark I, Carlsson GE. Treatment received, treatmentdemand, and treatment need for temporomandibular disorders in 35-yearold subjects. Cranio. 2002 Jan;20(1):11-7.
19. Thilander B, Rubio G, Pena L, de Mayorga C. Prevalence of temporomandibular dysfunction and its association with malocclusion inchildren and adolescents: An epidemiologic study related to specified stages of dental development. Angle Orthod. 2002;72:146-154.

20. Juniper R. Temporomandibular joint dysfunction: a theory based upon electromyographic studies of the lateral pterygoid muscle. Br J Oral Maxillofac Surg. 1984;22:1-8.

21. Morawa AP, Loos PJ, Easton JW. Temporomandibular joint dysfunction in children and adolescents: incidence, diagnosis and treatment. Quintessence Int. 1985 Nov;16(11):771-7.

22. Henrikson T, Nilner M, Kurol J. Signs of temporomandibular disorders in girls receiving orthodontic treatment. A prospective and longitudinal comparison with untreated Class II malocclusions and normal occlusion subjects. Eur J Orthod. 2000;22:271-81

23. Macfarlane TV, Kenealy P, Kingdon HA. Twenty-year cohort study of health gain from orthodontic treatment: temporomandibular disorders. Am J Orthod Dentofacial Orthop. 2009 Jun;135(6):692. e1-8; discussion 692-3.

24. Egermark I, Carlsson GE, Magnusson T. A 20-yearlongitudinal study of subjective symptoms of temporomandibular disorders from childhood to adulthood. Acta Odontol Scand. 2001;59(1):40-48.

25. Magnusson C, Nilsson M, Magnusson T. Degenerative changes of the temporomandibular joint. Relationship to ethnicity, sex and occlusal supporting zones based on a skull material. Acta Odontol Scand. 2012 May;70(3):207-12.

26. Michelotti A, lodice G. The role of orthodontics in temporomandibular disorders. J Oral Rehabil. 2010 May;37(6):411-29.

27. Hoffmann J. Einfluss der pubertären Entwicklung auf Symptome kraniomandibulärer Dysfunktionen (CMD) im Kontext kieferorthopädischer Behandlungen. [dissertation]. Chemnitz; 2014.

28. Antunes AC, Pozza DH, Rodrigues LL, Guimaraes AS. Relationship between Orthodontics and temporomandibular disorders: A prospective study. J Oral Facial Pain Headache Spring. 2016;30(2):134-8.

29. Badel T, Pandurić J, Marotti M, Krolo I. Clinical Investigation of Temporomandibular Joint Arthrosis Frequency in Young Males. Acta Stomatol Croat. 2006; 40: 46-55.

30. Mingelli B, Cardoso I, Porfirio M, Goncalves S, Barretto V, Sociro A. Prevalence of Temporomandibular Disorder in Children and Adolescents from Public Schools in Southern Portugal. N Am J Med Sci. 2014 Mar;6(3):126-32.

31. Vrbanović E, Alajbeg, IZ. Long-term Effectiveness of Occlusal Splint Therapy Compared to Placebo in Patients with Chronic Temporomandibular Disorders. Acta Stomatol Croat. 2019 Sep;53(3):195-206.

32. Magnusson T, Egermark I, Carlsson GE. A longitudinal epidemiologic study of signs and symptoms of temporomandibular disorders from 15 to 35 years of age. J Orofac Pain. 2000;14(4): 310319.

33. Lisa Marx-Janson: Craniomandibuläre Dysfunktion Querschnittsstudie der Prävalenz im Einzugsbereich Tübingen (eine retrospektive Datenerhebung) [dissertation]. Tuebingen; 2011. 